старого кота, и он был очень напуган. Затем он вспоминает, что, когда он был студентом и посещал занятия по анатомии, у одного из трупов в анатомическом театре было такое же лицо, как у его пациента М.

Очень символична история двоюродного дедушки доктора Лори, который был выдающимся хирургом и сыграл решающую роль в его выборе карьеры. Именно он показал главному герою, что смерть не страшна, если знать, как все устроено в организме. Персонаж вспоминает, как он часто видел, как дядя Лори сидит под яблоней, ест и пьет, и как он не мог понять, почему этот великий хирург, чье имя упоминалось в медицинских учебниках, ведет такой образ жизни, который медленно убивает его. Он находит ответ на этот вопрос только в конце рассказа - дядя Лори просто “наполнял себя, потому что его жизнь была пустой”, такой же пустой, какой является жизнь Барбары и какой была жизнь М. Поэтому идея автора заключается в том, что если жизнь человека пуста, он пытается найти что-то, чтобы заполнить ее, будь то нездоровая пища, роман на стороне, реальные или воображаемые симптомы.

Проанализированные рассказы демонстрируют, что Г.Свифт - писательинтеллектуал, который выражает свои идеи с помощью эмоционально-насыщенных символов [7].

$$
* * *
$$

1. Доронина О.В. Малая проза в творчестве английских писателей второй половины XX века: $\mathrm{P}$. Тремейн, Г. Свифт, И. Макъюен. Дисс. канд. филол. наук [Текст] / О.В. Доронина.-М., 2003.-152 с

2. Иткин В. Грэм Свифт: «Мне не нравится ощущать себя Всемогущим»// Книжное обозрение: [сайт]. URL: http://www.book-review.ru/news/news1414.html (дата обращения: 24.05.2021).

3. Сатюкова, Е. Г. Феномен «английскость» в творчестве Гр. Свифта :автореф. дис. канд. филол. наук : 10.01.03 / Сатюкова Елена Геннадиевна. - Екатеринбург, 2012. - 22 с.

4. Стринюк, С. А. Человек и история в романах Гр.Свифта: «Водоземье», Отныне и навсегда», «Последние распоряжения» : автореф. дис. ... канд.филол. наук : 10.01 .03 / Стринюк Светлана Александровна. - Пермь, $2003-$ c. 22

5. British Fiction of the 1990s / Ed. by N. Bentley. - London and New York:Routledge, 2005. - $256 \mathrm{p}$

6. Lea D. Graham Swift. Manchester University Press, 2005. 228 p.

7. Malcolm D. Understanding Graham Swift. Columbia, South Carolina: University of South Carolina Press, 2003. 238 p.

8. Tew, Ph. The contemporary British novel. London: Continuum International Publishing Group, 2004. 205 p.

\title{
Порядина И.К. \\ Ономастика художественных произведений брянских авторов как средство патриотического воспитания школьников
}

Филиал Брянского государственного университета в г. Новозыбкове (Россия, Новозыбков)

doi: 10.18411/lj-06-2021-134

\section{Аннотация}

В статье раскрываются особенности применения на уроках литературы ономастики художественных произведений брянских авторов в качестве средства патриотического воспитания школьников. Ономастика обладает познавательным и патриотическим, историко-культурным и эстетическим значениями. В связи с этим основной задачей педагога при обучении литературе становится раскрытие этих значений в поэтонимах, что приводит к расширению кругозора школьников, формированию их патриотических чувств.

Ключевые слова: изучение поэтонимов на уроках литературы в школе, ономастика художественного текста, патриотическое воспитание, брянские писатели. 


\section{Abstract}

The article reveals the peculiarities of the use of onomastics of artistic works of Bryansk authors as a means of patriotic education of schoolchildren in literature lessons. Onomastics has cognitive and patriotic, historical, cultural and aesthetic meanings. In this regard, the main task of the teacher in teaching literature is to reveal these meanings in poetonyms, which leads to an expansion of the outlook of schoolchildren, the formation of their patriotic feelings.

Keywords: study of poetonyms in literature lessons at school, onomastics of artistic text, patriotic education, Bryansk writers.

Тема Брянщины проходит через большинство произведений П. Л. Проскурина (1928-2001). Когда писателя спрашивали о героях его дилогии («Судьба», «Имя твое»), он говорил, что почти все они из родной деревни Косицы. Он исследовал народный характер, раскрывая и тёмные его глубины, и нравственное величие. Нескрываема любовь писателя к народу, сочувствие его трудной судьбе. Читая произведения П. Л. Проскурина, понимаешь, что связь человека с землей - это то, что составляет основополагающее значение в формировании личности. Другие брянские авторы, ономастика произведений которых привлекается в работе, - это В. Д. Динабургский (1922-2018) и Н. И. Родичев (1925-2002).

Ономастическое пространство «брянского мира» отражается в именах и фамилиях героев: Гешка, Пал Сергеич, Пелагея, Марфа Закутна, Абакумова, Брюханов, Дерюгин, Дорожкина, Забродин, Карпутин, Онипко, Старостенко, Радионов. Референты собственных имен из произведений П. Л. Проскурина, В. Д. Динабургского, Н. И. Родичева конкретны, потому что они служат для обозначения реалий Брянского края.

Так, брянская бабушка Марфа изъясняется на простонародном языке, говоре. Она именует своих собеседников без личного имени. И эта особенность отмечается исследователями народно-речевой культуры Брянского края [4, с. 143-144]. Речь героев произведения Н. И. Родичева «Патриоты», Митьки и Фомы, отличается простотой, достоверностью: «Самое главное - немца стронули, немец ударился в бег!» [7, с. 5]. Эти брянские авторы творили во второй половине XX века. В это же время происходит действие большинства их произведений. Употребление поэтонимов обусловлено временем, отраженным в произведениях: так выражается хронотопность антропоэтонимов.

C референциальным значением поэтонима может быть связана информация о предполагаемом прототипе (прототипах) персонажа. П. Л. Проскурину Великая Отечественная война запомнились не только жестокостью оккупационного режима, страданиями, которые она принесла, но и глубоко запавшими в душу именами людей, не склонивших головы перед врагами. Многие из этих героев войны впоследствии стали прототипами его произведений. В романе «Судьба» основное внимание писатель уделяет изображению судьбы Захара Дерюгина, буденновского бойца, председателя колхоза в пору коллективизации, солдата, шесть раз бежавшего из фашистского плена, узника концлагеря, наконец высланного в Хибратский леспромхоз на Каму. В рассказе «Мост» Пётр Проскурин излагает историю отважной шестёрки разведчиков, которые, выполнив трудную боевую задачу, пробираются к своим из немецкого тыла. «В группу вошло шесть человек: «Батурин отобрал Сквориова, Рогова, Юрку Петлина, Веретенникова и еще одного из роты Шумилова - Tараса Григорьева, прославившегося своим умением снимать часовых бесшумно; цирковой артист, застигнутый войной в Ржанске» [6, с. 48]. На уроках литературы целесообразно проводить работу по поиску прототипов персонажей произведений брянских писателей. 
С использованием вымышленного ойкопоэтонима Ржанск связана особенность употребления имен собственных в произведениях П. Л. Проскурина. Например, основные события романа «Судьба» происходят в деревне Густищи Зежского района Холмской области, а также в городах Зежск и Холмск (названия населённых пунктов вымышленные). Подразумевается территория Севского района Брянской области, малая родина писателя. Автор намеренно видоизменил названия топонимов Брянской области, искажая их ровно настолько, чтобы они оставались узнаваемыми. П. Л. Проскурин употребляет реальные названия городов и областей, но рядом с ними функционируют и полностью вымышленные названия поселков. Поэтонимы в произведениях брянских авторов, таким образом, могут быть индивидуальноавторскими или иметь эквивалент в общенародном ономастиконе, могут быть именем существовавшего в реальности лица или представлять собой название реальной местности. Однако авторы именуют объекты исключительно художественной, т. е. созданной воображением, действительности [3, с. 19; 5, с. 139].

Изучение ономастики брянских авторов осуществлялось нами в рамках педагогической практики уже на первом уроке литературы. Школьникам предлагалось написать мини-сочинение на тему «Что в имени твоём?». Учащиеся указывали, что они знают о своем имени, о его происхождении и о том, почему их назвали так, а не иначе.

Основная работа по изучению поэтонимов осуществлялась во внеурочное время. Первым этапом работы стало изучение особенностей значения и происхождения имен, что позволило сформировать интерес учащихся к исследовательской деятельности. Школьники знакомились с ономастической терминологией - названиями ономастических классов. Затем учащиеся приступили к исследованию. Из произведений брянских писателей извлекались и анализировались имена, фамилии, прозвища героев. Ребята приходили к выводу о совпадениях антропоэтонимов и реальных имен их друзей и знакомых. Проводилось исследование фамилий известных жителей, названий улиц, озер, рек родного края, употреблённых в произведениях.

Следующий урок - «B мире имён собственных». Целью этого урока было стремление заинтересовать школьников выяснением роли собственных имен в жизни человека и общества. Данный урок сопровождался чтением литературных произведений брянских авторов. В ходе проведения занятия осуществлялось патриотическое воспитание школьников (подчеркивались духовная, нравственная и культурная ценности малой Родины).

Урок начался со вступительного слова учителя, в котором было дано понятие ономастики, рассказывалось о значении имен в современном мире. Далее представлялась карта «Страна Ономастика», на которой в качестве городов выступали разделы ономастики. Учащиеся путешествовали по названным городам. В каждом из городов выступали заранее подготовленные ученики, излагавшие информацию о том или ином разделе ономастики. Затем анализировались поэтонимы произведений брянских авторов с точки зрения их происхождения, значения в художественном тексте. Так, в ходе анализа романа «Судьба» П. Л. Поскурина учащиеся заполнили следующую таблицу:

\begin{tabular}{|l|ll|}
\hline $\begin{array}{c}\text { Tопопоэтонимы, имеющие } \\
\text { соответствие в реальности }\end{array}$ & & Вымышленные топопоэтонимы \\
\hline - Косицы & $\bullet$ & Густици \\
- Севск & $\bullet$ & Зежск \\
- Брянск & $\bullet$ & Холмск \\
\hline
\end{tabular}


В конце урока делался вывод о том, зачем нужны имена собственные, что лежит в основе их происхождения и какова история их возникновения. В качестве домашнего задания учащимся предлагались следующие задания.

1. Написать реферат на одну из тем (по выбору обучающегося):

Топопоэтонимы Зежск и Холмск в произведениях П. Л. Проскурина.

Антропоэтонимы в повести Н. И. Родичева «Брянский вокзал».

Прозвища героев произведений В. Д. Динабургского (Бобыль, Грибная история, Семнадцать зарубок).

2. Выучить наизусть стихотворение В. Д. Динабургского «Осень в Брянске.

3. Написать сочинение на следуюшую тему (по выбору): «Родная природа в произведениях брянских авторов», «Брянская природа в зеркале поэзии», «Лирический герой стихотворения».

Внеурочная работа в 10-ом классе, в частности, была представлена занятием по теме «Ономастика и литературное краеведение. Брянская область». Была организована работа, посвященная изучению истории названий городов Брянской области. У учащихся формировалось национальное самосознание, чувство патриотизма. Перед учащимися ставился, например, проблемный вопрос: «Откуда пришел ойконим Брянск?». Учитель озвучивал официальную версию, школьники излагали другие версии. Затем учитель предлагал обратиться к произведениям брянских авторов. Учащиеся сравнивали названия городов и сёл - реальных и вымышленных. Кроме того, каждый из учащихся излагал содержание заранее подготовленных сообщений. Школьники пришли к выводу, что поэтонимы достаточно широко употребляются в произведениях брянских авторов (к примеру, гидропоэтонимы Сев, Нерусса, Десна, Мариия).

Изучение ономастики должно сопутствовать методам, применяемым на уроках литературы. Бесспорно, что поэтонимы родного края, помогают решать задачи патриотического воспитания. Их изучение должно включаться в содержание уроков литературы. Методически оправданно и целесообразно включение ономастического материала как в уроки литературы, так и во внеурочные занятия по литературе. Нельзя не отметить метапредметный характер ономастики. С именами собственными школьники встречаются на уроках русского языка, географии, истории, астрономии. Основная роль в работе с ономастикой художественных произведений отводится учителю, который проводит работу по выявлению происхождения и значения поэтонимов путем, развивая также логическое мышление, эстетический вкус и стилистическое чутье обучающихся.

$$
* * *
$$

1. Динабургский В. Д. Лунарий: Стихотворения. - Брянск: Брян. торгово-пром. палата, 2001. - 139 с.

2. Динабургский В. Д. Явь: стихотворения. - Брянск: Дебрянск, 1998. - 141 с.

3. Пронченко С. М. Имена собственные в поэтической системе графа А. К. Толстого: парадигматический и синтагматический аспекты // Rhema. Рема. - 2018. - № 2. - C. 16-38.

4. Пронченко С. М. Имена собственные в речи сельских жителей юго-запада Брянской области (по материалам полевых исследований) // Известия Южного федерального университета. Филологические науки. - 2019. - № 3. - C. 138-147. - DOI: 10.23683/1995-0640-2019-3-138-147.

5. Пронченко С. М. Поэтонимы в художественной системе исторического романа графа А. К. Толстого «Князь Серебряный» // Новый филологический вестник. - 2021. - № 1. - С. 138-147. DOI: $10.24411 / 2072-9316-2021-00011$.

6. Проскурин П. Л. Собрание сочинений: В 5-ти т. - М.: Современник, 1981-1983.

7. Родичев Н. И. Живет в деревне человек...: Очерки, рассказы. - Москва: Правда, 1971. - 48 с. 